\title{
Belphégor
}

\section{Quality Sells}

International Bestsellers in the Dutch Literary Field around 1936

\section{Ryanne Keltjens}

\section{(2) OpenEdition}

\section{Journals}

Electronic version

URL: http://journals.openedition.org/belphegor/1017

DOI: $10.4000 /$ belphegor. 1017

ISSN: 1499-7185

Publisher

LPCM

\section{Electronic reference}

Ryanne Keltjens, «Quality Sells », Belphégor [Online], 15-2 | 2017, Online since 21 November 2017, connection on 20 April 2019. URL : http://journals.openedition.org/belphegor/1017 ; DOI : 10.4000/ belphegor. 1017

This text was automatically generated on 20 April 2019.

\section{(c) $($ )(9)}

Belphégor est mis à disposition selon les termes de la Licence Creative Commons Attribution - Pas d'Utilisation Commerciale - Pas de Modification 4.0 International. 


\title{
Quality Sells
}

International Bestsellers in the Dutch Literary Field around 1936

\author{
Ryanne Keltjens
}

\section{Introduction}

1 Although middlebrow literary culture is often associated with the domestic and the national, it can at the same time be related to developments on the international book market. During the first half of the twentieth century the increasing global circulation of literary works and the growing influence of international commerce on the publishing industry contributed to the emergence of an international bestseller culture. Following Pascale Casanova's analysis of the literary world from internationalism to globalization, I conceive of this international bestseller culture as a new stage in the gradual development towards the globalized book market as we know it today, which can be characterized by new organization models for the production and promotion of literature within international mass-media businesses, and a focus on immediate profitability. ${ }^{i}$ Typical of this specific stage are an increased production speed, a closer entanglement of literature with other (mass) media and a growing importance of marketing strategies. In the international bestseller culture of the thirties, translations of promising works were published immediately after the original and a movie adaptation was prepared right away. Extensive marketing strategies were set up to draw the attention of the audience to the work at hand, often drawing on the evolving celebrity culture of the period. ${ }^{\mathrm{ii}}$ The most obvious example of such an international bestseller may well be Gone with the Wind (1936) by Margaret Mitchell, which was published in about forty countries, was turned into an extremely successful motion picture in 1939 and had reached total sales of over 28 million copies worldwide in 1987.iii

2 The emergence of this international bestseller culture can be explained by a complex constellation of social, cultural and technological developments, including cheaper printing processes and optimized distribution possibilities. ${ }^{\text {iv }}$ A crucial factor was the growing demand for literary works, a side-effect of improved education, which increased literacy and made literature and culture accessible for broader groups. ${ }^{v}$ As cultural 
participation increased, cultural distinction became more important. Both the traditional cultural elite and new intermediaries (publishers, critics) who tried to serve these new reader groups increasingly felt the need to distinguish themselves, promoting and defending their ideas about literary quality and taste. ${ }^{\text {vi }}$

As previous research has shown, such distinction mechanisms in the interwar years can be fruitfully studied from a tripartite perspective, introducing the concept of middlebrow. vii This approach implies an adjustment to Bourdieu's conception of the field as determined by the two poles of restricted and large-scale production, carving out a 'distinctive in-between space ${ }^{\text {viii }}$ on this continuum. ${ }^{\text {ix }}$ The inherent flexibility of the concept of middlebrow allows me to propose a specific application here, using it as a heuristic device to analyze the responses to this international bestseller culture from an institutional point of view. Bourdieu's ideas about cultural distinction can offer a fruitful perspective in this case, because foreign literary works inevitably played a role in domestic debates about cultural hierarchies. ${ }^{x}$

In the Netherlands for instance, critics feared that the increasing importation of low quality translations would push aside qualitatively superior works by Dutch authors, reflecting a certain pride in the national literature. ${ }^{x i}$ Such fears were not completely unfounded in a small book market in which literary works in the original language had only recently become commercially attractive for publishers. ${ }^{\text {xii }}$ The Dutch book market can be characterized as peripheral : the literary system is dependent on other, larger literatures, which is illustrated by the large amount of translations as compared to the local production. ${ }^{\text {xii }}$ In my contribution I want to investigate how this peripheral market was affected by the upcoming international bestseller culture of the thirties, focusing on the adaptation, marketing and critical evaluation of Margaret Mitchell's Gone with the Wind (1936) and Katrina (1936) by Sally Salminen in the Netherlands.

\section{Modesty, marketing and middlebrow : Sally Salminen's Katrina}

5 In the course of 1939 the Dutch florist M. Vellekoop had cultivated a lovely, dark-coloured chrysanthemum which he named after Sally Salminen, the famous writer of the international bestseller Katrina (1936). A bouquet of these flowers was sent to the residence of the successful author in Finland by the Royal Dutch airline, and in a friendly letter Salminen replied to Vellekoop that she was touched by his gracious gesture. ${ }^{\text {xiv }}$ That this was more than just a sympathetic initiative of an enthusiastic book-loving florist, becomes apparent if we take a look at the activities of the publisher of the Dutch translation of the novel, Andries Blitz (1890-1942). ${ }^{\mathrm{xv}} \mathrm{He}$ offered booksellers the possibility to decorate their shop-windows with a bouquet of Sally Salminen chrysanthemums, accompanied by some well-prepared advertising material and of course a pile of copies of Katrina. ${ }^{\text {viv }}$ The timing of this charm offensive at the end of November was significant, as the celebration of the Dutch feast of Sinterklaas (St Nicholas) on the fifth of December would traditionally account for a significant increase in book sales. ${ }^{\text {xvi }}$ This anecdote is illustrative of the publisher's creative and extensive marketing strategies.

Blitz had been working at the publishing house Scheltens \& Giltay for a while when he started his own company in January 1929. .viii $^{\prime}$ After the Second World War he became known for his extremely cheap 'ABC-novels', which were introduced in 1938 as the Dutch 
equivalents of the Penguin pockets (since 1935) and cost only thirty-five cents each. ${ }^{\text {xix }}$ His publisher's list further included adventure novels by the famous Dutch aviator Anton Viruly and the French author Antoine de Saint-Exupéry, the social-ironic bestseller De kleine parade (The Small Parade) by Henriëtte van Eyck and some works by Jewish authors. ${ }^{x x}$ From 1936 on Blitz started publishing translations of popular Swedish works, which were translated by a Dutch newspaper correspondent in Stockholm, Charles Gl. Behrens. xxi The commercial potential for popular Scandinavian literature may have increased at that time as a result of the enormous success of the Björndal Trilogy (1933-1935) by the Norwegian author Trygve Gulbranssen. ${ }^{\text {xxii }}$

7 Sally Salminen was probably one of Blitz's most successful authors. She had grown up on the Åland Islands, in the Swedish-speaking part of Finland, but had left her home country to work as a housemaid in New York. In her scarce spare time she wrote her debut novel about the life of a strong woman in the unequal, rural society of the Åland Islands in the early twentieth century. After some unsuccessful attempts to get the work published, Salminen participated in a novel-writing competition, which was organized by the Finland-Swedish publishing house Schildts in cooperation with the Swedish company Wahlström \& Widstrand. Winning the prize changed her life completely: from an unknown housemaid she turned into a world-famous author. The original Swedish edition of Katrina, published in October 1936, was an instant bestseller, reprinted fifteen times in the first three months. The novel was soon translated into more than twenty other languages, including French, Italian and German. ${ }^{\text {xxii }}$

8 Andries Blitz was well-informed about the Scandinavian literary sensations of the day and seized his chance. He probably obtained the publication rights of Katrina within a few weeks ${ }^{\mathrm{xxiv}}$ and succeeded in publishing the Dutch translation only four months after the original, in February 1937. ${ }^{\mathrm{xv}} \mathrm{He}$ set up an active marketing campaign putting advertisements in just about all national and local newspapers. In his first, full-page announcement of the novel in the Nieuwsblad voor den Boekhandel (Newspaper for the Book Trade), Blitz described it as a work 'which possesses all the qualities needed to become a tremendous success', emphasizing the commercial potential of the novel (figure 1). 


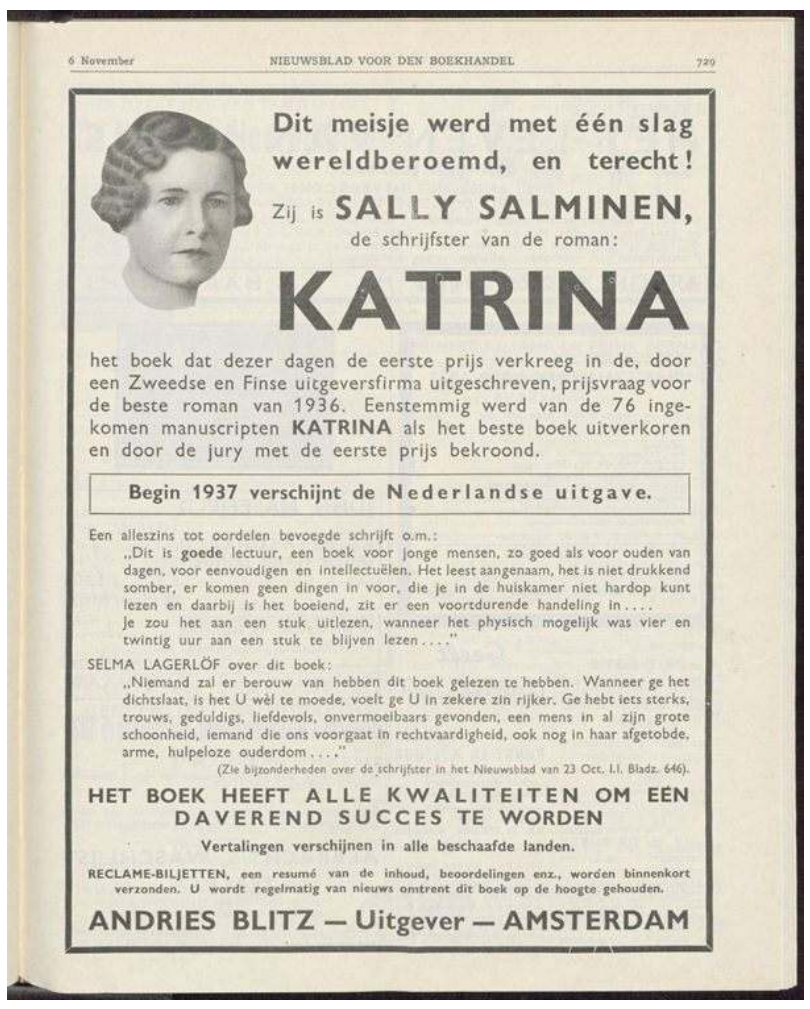

Figure 1 : advertisement for Katrina in $N v d B$

9 The advertisement contained a portrait of Salminen and a short account of her rocketing career :

This girl became world-famous in one blow, and rightly so! / she is SALLY SALMINEN, author of the novel: / KATRINA / the book which has won first prize for the best novel of 1936 in a competition held by a Swedish and Finnish publishing house. KATRINA was chosen unanimously from 76 incoming manuscripts as the best book and was awarded the first prize by the judging-committee. ${ }^{\text {xxi }}$

Blitz actively propagated the Cinderella story of a young girl of modest descent writing a global bestseller out of the blue, an image which circulated in newspapers worldwide. ${ }^{\text {xxvii }}$ His advertisements focused predominantly on her unexpected success rather than on the content of the book. In the course of 1937 Blitz published a photo book about the author, with the title Sally Salminen: de romantische geschiedenis van een schrijfster en haar roman met foto-illustraties (Sally Salminen: the Romantic History of a Writer and her Novel with Photographic Illustrations) ensuring that all readers knew who Sally Salminen was and what she looked like. He also invited Salminen to visit the Netherlands and meet her Dutch fans. ${ }^{\text {xxvii }} \mathrm{He}$ did not succeed, however, because of the increasing political instability in Europe at the end of the thirties.

Such forms of 'personality promotion'xxix were relatively new in the Dutch literary field of that time. The genre of the author interview for instance had only recently become a common phenomenon in the Netherlands. ${ }^{\mathrm{xxx}}$ Blitz's marketing strategy shows the increasing importance attributed to the author figure as a public persona, representing commercial value as a brand name on the (international) book market. ${ }^{\mathrm{xxxi}}$ Furthermore it demonstrates the importance of other media, in particular newspaper journalism, in the mediation of such author images. ${ }^{\text {xxii }}$ Blitz tried to cultivate an existing image of 
Salminen, which was originally created by journalism, and adapted it to his own commercial goals. ${ }^{\text {xxxiii }}$

Although exact sales records are lacking, Katrina did indeed become a bestseller in the Netherlands, making it to number two on the 1937 list of 'most demanded books' in the periodical Haagsche Post (The Hague Mail). ${ }^{\text {xxiv }}$ In 1939 the tenth jubilee edition came out and after the war the novel kept selling : the twentieth edition was published in 1950. ${ }^{\mathrm{xxv}}$ Salminen proved to be no nine days' wonder, as seven of her other works were subsequently translated into Dutch. ${ }^{\text {xxvi }}$ Blitz himself never knew about the postwar popularity of his star author. As a Jewish publisher, he was deported to Auschwitz and died in August 1942. xxxvii By then, his company had already been liquidated and his publishing list was taken over by the publishers Holkema \& Warendorf. ${ }^{x x v i i i}$ After the war, his widow Dé (Deborah) Tas administered his estate and kept the publishing house going. xxxix On her invitation Sally Salminen finally came over to Amsterdam in June 1946, where she gave a lecture about the similarities and differences between Norwegians, Swedes, Finns and Danes. ${ }^{\mathrm{xl}}$

Back in 1937, the launch of Katrina in the Netherlands triggered complaints about what was perceived as an international flood of low quality translations overrunning the Dutch market. ${ }^{x l i}$ Scandinavian works were considered a substantial part of this problem. Though in reality English and American works dominated the translation market, translations of Scandinavian works indeed accounted for a remarkable share of literary production in the Netherlands as compared to other small languages. ${ }^{x \text { lii }}$ So the image of Scandinavian dominance was exaggerated, but the reaction explicable. Salminen's novel, however, was considered a positive exception to the bulk of Scandinavian literature. ${ }^{\text {xlii }}$ To justify this claim, Dutch reviewers set the work apart from its Scandinavian origins and related it to domestic hierarchies of quality. As such, Katrina was drawn into Dutch debates about the middlebrow novel. I want to highlight two aspects of this practice here : the moral values attributed to the novel and the modesty and simplicity ascribed to the work and its author.

In the first place, the importance of Katrina to Dutch reviewers was determined by its 'ethical value'. ${ }^{\text {liv }}$ The story about a woman who persistently tries to survive under the most difficult circumstances - a problematic marriage, labouring as a serf in a tough climate and losing contact with her children, made a profound impression on (professional) readers. Some of them wrote that they were emotionally touched by the work. ${ }^{\text {lv }}$ According to J.G. de Haas the idealism of the main character could function as an 'example for everybody in our disrupted society who is despondent' and in that sense the novel had 'significance for the current generation'. xlvi P. Hardy maintained that Katrina 'without illusions about life demands human compassion, without which the lives of millions would become like hell'. . xvii Salminen was praised for the 'deep love with which [the author] wrote this novel'xlviii and the 'heart' that was beating in the book. ${ }^{x l i x}$ These critics thus valued the emotional effect of the book on readers, who would find support, comfort and hope in it. With such statements, the novel was contrasted with some of the supposedly typical characteristics of Scandinavian literature. Scandinavian works were considered 'concise', 'sober' and 'gloomy' in style, containing 'plain ethics' and an 'uncomplicated view of problems.'. Katrina however was an exception to Scandinavian severity, because in the end its tone was optimistic: 'Even in the darkest moments, an uncompromising courage to face life and a natural happiness were maintained', as the 
reviewer Gabriël Smit wrote..$^{\text {li }}$ And it was this optimistic tone, this hopeful message, that made Katrina unique.

At the same time, the reception of the novel touched upon Dutch discussions about literary quality and cultural hierarchies. References to ethical values and reading pleasure and key words such as 'love' and 'heart' indicate that Katrina was counted among a broad category of literary works in the middle domain of the Dutch literary hierarchy. ${ }^{\text {lii }}$ And indeed De Haas explicitly positioned the novel somewhere in between high art and entertainment, doubting whether the predicate 'masterpiece' would be applicable in this case and at the same time praising its distinctive qualities. ${ }^{\text {liii }}$ Like many other reviewers in the interwar period, he promoted morally sound fiction as an alternative to mere entertainment, which was considered harmful. liv Furthermore, he opposed the emotional qualities of Katrina to the rational perspective of the literary elite and its intellectualistic world view :

it is a healthy and powerful book with living people, a novel with a heart, which shows us life in a specific social environment without much aesthetic decoration, open, pure and not in the least through the deformed lens of intellectualism, which is still rampant in our literature. ${ }^{\text {.v }}$

Although he acknowledged the dominance of this view, ${ }^{\text {lvi }}$ De Haas defended an alternative perspective based on the moral values of literature and the taste of the general reader. .vii $^{\text {vi }}$ This position-taking is typical of a broad and heterogeneous group of reviewers who wanted to inform the general audience about the literary production of the day. ${ }^{\text {lviii }}$ These 'middlebrow critics', as scholars of this period have recently termed them, believed in the social values of literature and thought of themselves as guides, mentors or mediators between literature and the reader. ${ }^{\text {lix }}$ While accepting the lower status attributed to them in the critical hierarchy of the thirties, they self-consciously proclaimed their critical aims and ideas about literary quality as a legitimate alternative to the dominant perspective of elite or 'highbrow' criticism. ${ }^{1 \mathrm{x}}$

The positioning of Katrina as a middlebrow novel is effectuated secondly by the discourse of modesty and simplicity used in relation to both the work and its author. Under the influence of Salminen's prominence in the newspapers and Blitz's marketing strategies almost all reviewers reproduced the image of an ordinary girl who had suddenly turned into a celebrity, stressing her modest background. ${ }^{1 \times i}$ At the same time they described her novel as 'simple' and 'pure', drawing a direct link between the author's personality and the formal and aesthetic characteristics of her work. ${ }^{1 x i i}$ This striking emphasis on the simplicity of the novel and its author, which was clearly considered a positive trait, was used to demarcate Katrina from lower cultural spheres. Many reviewers criticized the commercial circus around the novel: its commercial launch with a 'barrage of advertisements and impressive slogans' and the literary prize as a dubious phenomenon, capitalizing on the sensationalism of the masses. ${ }^{\mid x i i i}$ Again, the novel was considered an exception because of its high quality, which legitimated its commercial success. ${ }^{\text {lxiv }}$ At the same time, Salminen herself was believed to have successfully resisted the dangers of world fame by remaining as modest as she had always been. ${ }^{\mathrm{kx}}$ So by stressing the simplicity of the novel and the modesty of the author, these critics were drawing a clear boundary between the middle sphere of 'good books' and the extremely commercial and morally dangerous domain of 'lowbrow' literature. 


\section{Prices, piracy and pedagogy : Margaret Mitchell's Gone with the Wind}

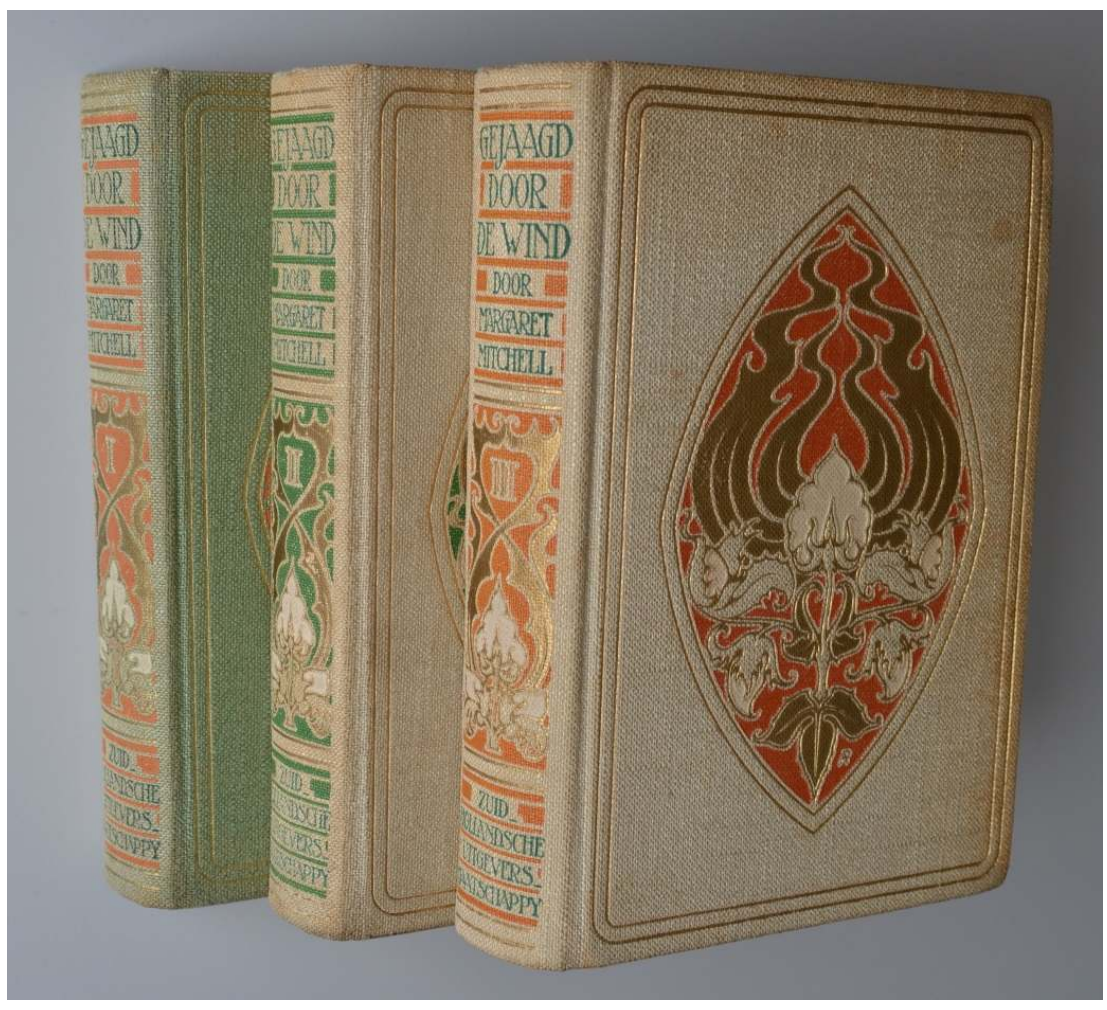

Figure 2: Dutch covers of Gone with the Wind trilogy

Comparing the Dutch edition of Margaret Mitchell's novel Gone with the Wind (1936) to its original makes one wonder whether the two actually contain the same story. Mr. Ad. M.C. Stok, director of the publishing house Zuid-Hollandsche Uitgevers Maatschappij (ZHUM), had turned the American bestseller into a trilogy with a completely different look and feel. Instead of the large, dark brown font on a soft yellow background and a small image of the main characters on the American dust jacket, the Dutch covers featured a huge cotton plant in art nouveau style, in three different colour variations (figure 2). Furthermore, the volumes each contained original drawings by the Dutch artist Anton Pieck, who was known for his romantic and nostalgic style. ${ }^{\text {lxvi }}$ On top of that, the title pages of each volume bore newly-made Dutch titles: Vuur over land (Fire over Land), Als een vlam in de storm (Like a Flame in the Storm) and Het zaad ontkiemt (The Seed germinates). In other words: Stok made far-reaching changes to the original to adapt Gone with the Wind to the alleged demands of the Dutch reading audience. ${ }^{\text {Ixvii }}$

One of the issues he had to deal with was the price Dutch readers were able and willing to pay for the novel. Because of the small language area, the Dutch translation of a voluminous book like Gone with the Wind would easily become too expensive for ordinary readers. ${ }^{\text {Ixvii }}$ Even by American standards the book was an expensive buy. It was only the second American novel until then with a price of three dollars, the first being the voluminous historical novel Anthony Adverse (1933) by Hervey Allen. ${ }^{\text {lix }}$ In the Dutch case, the majority of books around 1935 cost less than two guilders, although the prices were gradually increasing at that time due to a rise in paper costs. ${ }^{1 \times x}$ The reasons for the 
division of the Dutch edition into three volumes were thus mainly economic. Costing 2,40 guilders each for the sewn edition and 3,25 guilders for the bound edition, the volumes were affordable separately. Still the whole trilogy was quite an investment for ordinary readers, but Stok believed that most of them would be enchanted by the first volume and would not be able to resist completing their collections. In an advertisement in $N v d B$, Stok sang the praises of his trilogy as a safe investment for bookshop owners, estimating that $95 \%$ of the buyers of the first volume would in the end buy the other two volumes as well. lxxi

Besides economic considerations, cultural arguments may also have played a role, as suggested by an anonymous reviewer who stated that ZHUM had met 'our national conventions' by splitting the tome into three volumes. ${ }^{\text {Ixxii }}$ This reviewer was probably referring to debates about the status of the novel which had been going on in the Netherlands since the second half of the twenties. The young post-war generation of writers wanted to break with the realist tradition and their resistance was directed amongst other targets at the voluminous proportions of these works. ${ }^{\text {lxxii }}$ Stok may have wanted to comply with the 'modern' call for brevity.

21 The first volume of Gejaagd door de wind came out well over a year after the original, in the late fall of 1937, and the second and third volumes were published at monthly intervals, keeping the audience in some suspense. ${ }^{\text {lxiv }}$ The launch of the Dutch trilogy was accompanied by a modest marketing campaign in Dutch national and local newspapers and periodicals. In his advertisements Stok focused on the incredible sales figures the novel had achieved in the United States (figure 3) :

An American bestseller means... nothing! / A big American bestseller means... a little! / An enormous American bestseller means... something! / A book event unparalleled in this world means... something important ! [...] Because figures are more convincing than any other type of proof. [...] One and a half million copies in America $^{\mathrm{lxxv}}$

At the same time he stressed the autonomy of the Dutch audience, ascribing to this readership a taste independent of American book market successes. Still the US sales figures were mentioned in almost every advertisement Stok put in the paper and apparently functioned as the main argument to convince readers to buy the work. In contrast with Blitz's campaign for Katrina, Stok did not refer to the personality or international fame of the author. In general, Margaret Mitchell's personal life was far less prominent in the Dutch daily press than Salminen's, whose marriage for example was all over the newspapers, including pictures of the happy couple. . $x x v i^{3}$ 


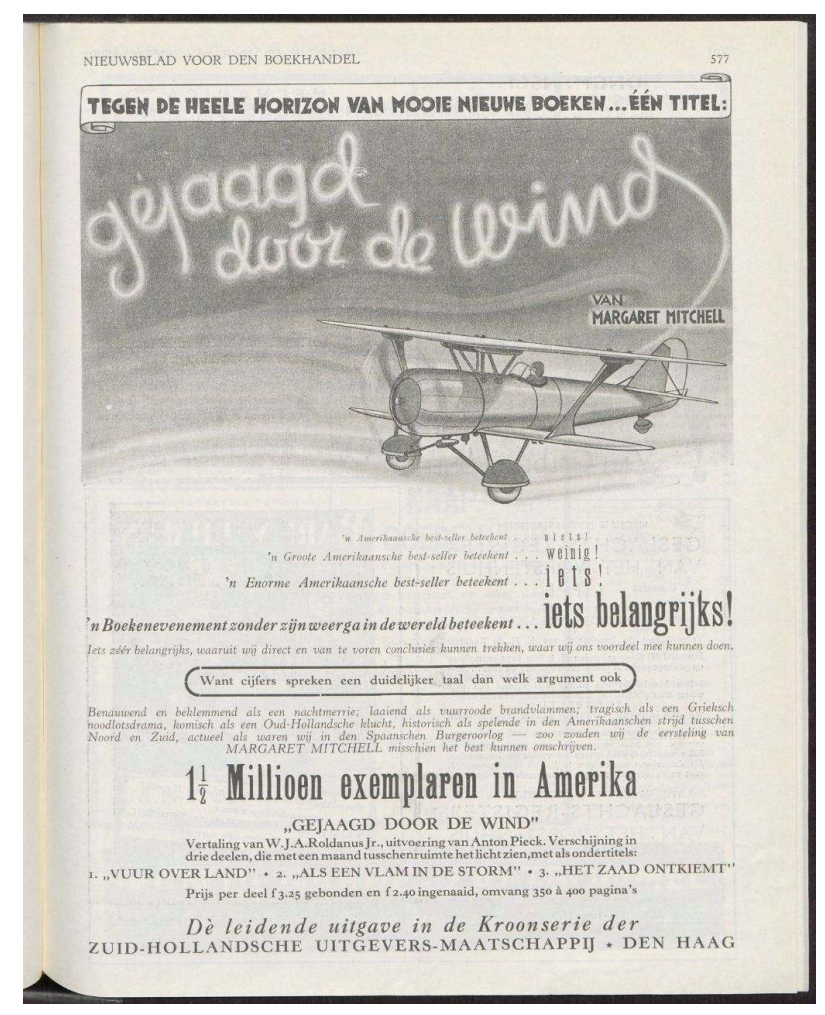

Figure 3: advertisement for Gone with the Wind in $N v d B$ became more important, ${ }^{1 \times x v i i}$ as is clearly demonstrated by the case of Gone with the Wind. Margaret Mitchell was negotiating with another Dutch publisher when she found out that ZHUM was preparing a translation of the novel without her authorization. She and her publisher Macmillan pressed charges against ZHUM for piracy, trying to prevent the novel's publication in the Netherlands, but initially lost. ${ }^{\text {lxxvii }}$ In January 1938 Mitchell and her legal advisors succeeded in suspending sales of the Dutch edition by an injunction, making sure it could no longer be distributed. lxxix Although the novel was released for distribution after six weeks, ${ }^{1 \times x x}$ Mitchell wanted to 'take it through every court in Holland' lxxi - which she did. At the same time, she was taking out legal actions against - amongst others - Japanese and Chinese publishers, and all kinds of other different parties who tried to profit from her success. ${ }^{\text {lxxxii }}$

All of this could happen because the United States had not yet ratified the Berne Convention, which regulates the international protection of copyright. lxxxiii American authors often used the so-called 'backdoor to Bern' to gain protection for their works, which meant that they published their works first or simultaneously in a country which had ratified the Convention. . $^{\text {Ixxiv }}$ For this reason, Gone with the Wind was published at the same time in New York and in Canada. ZHUM's attorney, however, successfully argued that this course of events was a feint. . $^{\operatorname{lxx} v}$ Stok had already registered his intended translation of the novel with the Dutch Commissie voor het Vertalingsrecht (Committee in Translation Rights) halfway through 1936, and this right was granted to him on the assumption that the novel was published in the United States only, and therefore unprotected by the Berne Convention. ${ }^{\text {lxxxvi }}$ Stok and the Committee probably heard about the Canadian edition for the first time about a year later, when Mitchell and Macmillan came up with the lawsuit. ${ }^{\text {lxxvii }}$ In September 1945 ZHUM and Mitchell finally reached an 
agreement, allowing Mitchell 28,500 guilders for royalties and other costs, which she

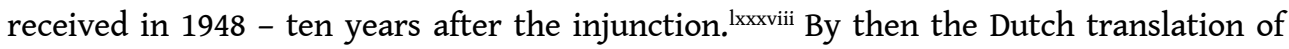
Gone with the Wind had sold around 50,000 copies in the Netherlands and 7,000 in Belgium. lxxxix

From the moment of the injunction, the legal case against ZHUM was widely discussed in the Dutch media. ${ }^{x c}$ Stok himself referred to the Dutch Committee on Translation Rights and argued in $N v d B$ that his publication was legal. ${ }^{x i}$ As Mitchell herself also noticed, the media sided with Stok, stressing his 'good faith' and defending him against the accusation of piracy, which was considered a grave insult. ${ }^{\text {xcii }}$ At the same time, American writers were considered victims of their own government that refused to take care of its authors' legal rights. As an anonymous contributor to $N v d B$ argued :

In the meantime, the case has been brought before the Dutch court and we shall therefore refrain from expressing our opinion. It is however remarkable that the indignation of the Publishers' Weekly's editorial board about this presumed "piracy" is not directed against the fact that the United States have still not joined the Berne Convention. For that would immediately put an end to all "robberies". xciii

Such statements reflected a sense of moral superiority and pride in the professional organization of the Dutch literary field. ${ }^{\text {xiv }}$ These sentiments may have been reinforced by the fundamental inequality between the peripheral Dutch market on the one hand, which was economically dependent on the importation of foreign literary works, and the American book market on the other, which was rapidly moving towards the centre of a globalized bestseller culture in this period. ${ }^{\mathrm{xcv}}$ Dutch publishers had been defending unauthorized translations throughout the nineteenth century, because they were the mainstay of the Dutch book business. ${ }^{\text {xcvi }}$ In the Dutch literary field of the thirties, the exploitation of an unauthorized literary work did not seem to affect the moral status of a publisher but apparently was still perceived mainly as an economic concern. Illustrative of this attitude was Stok's sale of the copyright of the Dutch edition of Gone with the Wind to a Belgian publisher, in the period when negotiations about Mitchell's royalties were in full swing. ${ }^{\text {xcvi }}$ Furthermore, Stok used the injunction as a means to draw even more attention to his publication based on its sensational genesis :

THE BOOK WHICH HAS BEEN EMBARGOED FOR 6 WEEKS / "Gone with the Wind" / by MARGARET MITCHELL which sold almost 2.000 .000 copies in America is available again. / Limited edition! Place an order today ! xcviii

Although not every reviewer agreed with the critics C. Tazelaar and Jeanne van SchaikWilling that Gone with the Wind was 'a masterpiece', xcix Dutch reactions to the novel were predominantly positive. Even though the trilogy was considered a genre of lower esteem, ZHUM was praised for its excellent choice to publish this international bestseller of high quality, indicating its position in the aforementioned middle domain. ${ }^{c}$ Just like Katrina, Gone with the Wind was drawn into Dutch debates about the middlebrow novel, but unlike Salminen's novel it apparently did not need to be explicitly distinguished from the lowbrow domain. Instead, Dutch reviews focused on the pedagogical and social values of the novel. ${ }^{\text {i }}$

In the first place, Gone with the Wind was considered an important novel because it provided readers with historical knowledge about the American Civil War. As an anonymous reviewer remarked: 'for the knowledge it provides about this so unknown Southern part of the States it [the novel] could be called a beautiful documentary'cii and the reviewer Pearce Delgado wrote : 'Indeed this period, this way of life is "Gone with the Wind", but Margaret Mitchell's book will remain as a worthy work for its remembrance 
$[\ldots]^{c}{ }^{c i i i}$ The instructive function of the novel was not just mentioned as an explanation for its success in the United States, but was also considered valuable for the Dutch audience, because it offered them a new perspective on American history : 'The American civil war, that we have learned to view from the perspective of the Yankees, as we were raised with "Uncle Tom's Cabin", is painted in all its components, from the viewpoint of the slave owners of the Southern States. ${ }^{\text {'iv }}$ In the second place, Mitchell was praised for her vibrant style of writing and in particular for the vital and persuasive characters she had created. ${ }^{\mathrm{cv}}$ Like Salminen she was considered 'a born storyteller'cvi and Dutch reviewers emphasized the emotional effects of the novel : the 'fascinating' and 'gripping story', that would 'stick in one's mind'. cvii

29 For the female critic Van Schaik-Willing both of these aspects were important reasons to try and convince 'literary connoisseurs' of the qualities of this 'beautiful work of art'. cviii In her review, she criticized the highbrow attitude of 'prune-faces, named lettrés' towards the novel in general, particularly when it was written by a woman. In their crusade against voluminous realist novels elite critics were led by prejudices, she argued in a satirical manner : 'A novel, he thinks, a novel in these times! It must be rubbish. Another lady writer like (the reader may fill in names here). In that manner, a member of the literary elite will pull a long face as soon as he holds this voluminous Bible in his hands. . Van Schaik-Willing was not just referring to the discussion about the size of novels I described earlier, but also to the general resistance of the younger generation of critics against novels written by women, which were pejoratively referred to as 'ladies' novels'. ${ }^{\text {cx }}$ As previous research has shown, these popular novels share formal and institutional characteristics with the British middlebrow novel of the interwar period. ${ }^{\text {cxi }}$ A remarkable similarity is the assumed relation between literary quality and masculinity: many popular novels were considered inferior because they were written and supposedly read by women. ${ }^{\text {cxii }}$ In her review Van Schaik-Willing defended an alternative view on literary quality, which was less informed by knowledge about the author or formal characteristics of the work. In this way she joined the impartial and democratic perspective Dutch middlebrow critics actively propagated as an alternative to 'highbrow' criticism, which was considered elitist, modish and prejudiced. ${ }^{\text {xiii }}$

\section{Concluding remarks}

30 As the cases of Katrina and Gone with the Wind have shown, the practices of Dutch publishers indicate that they were fully aware of the commercial potential of international bestsellers on the local book market. Both Blitz and Stok obtained the translation rights of these works as soon as they could and produced an edition which was adapted to local demands. Stok's strategy mainly focused on the materiality of the work, turning Gone with the Wind into a trilogy to meet the economic limitations of a small language area and tailoring its appearance to the assumed taste of the Dutch audience. He also demonstrated his business acumen in dealing with a protracted international copyright case. Blitz on the other hand employed extensive modern marketing strategies and tried to cultivate Sally Salminen's public persona while positioning Katrina on the Dutch market. The success of his methods is illustrated by the responses of Dutch critics, who adopted the image of modesty and simplicity in their reviews, showing the growing importance of personality promotion in the globalizing book market of the late thirties. 
31 As both novels were already bestsellers abroad and would soon become bestsellers in the Netherlands as well, critics were forced to deal with the commercial aspects of these works in their reviews. In the case of Katrina they used Salminen's author image to position her work within the middle sphere of their literary hierarchies, promoting the work as a morally sound alternative to mere entertainment. As such, the novel was drawn into local debates about the (middlebrow) novel and became less 'foreign'. Gone with the Wind was praised for its pedagogical and psychological qualities and ranked somewhat higher within the middle domain. Both novels triggered position-takings by critics who defended their ideas and methods against the perceived dominance of elite or highbrow criticism.

These findings confirm Isabelle Kalinowski's argumentation that each literary field is in essence a national field and that the reception of foreign works in the first place is effectuated according to the values and hierarchies of this importing field. cxiv Although intercultural exchange may have increased with the rise of an international bestseller culture, the reception of a literary work will always take place within a specific national context. ${ }^{\mathrm{cxv}}$ The concept of middlebrow can help to unravel the ways in which 'foreign' works affected a specific national literary field: on the level of the literary work itself, which is positioned within a local literary hierarchy, and on the level of critical positions, as a means for reviewers to claim their position within the national critical domain. ${ }^{\text {cxvi }}$

\section{BIBLIOGRAPHY}

\section{Primary sources}

\section{Advertisements and short articles in :}

NvdB (Nieuwsblad voor den boekhandel), volumes 103-106, 1936-1939. Consulted via www.delpher.nl on November 25, 2015.

De Telegraaf, 1938, 1940 and 1950. Consulted via www.delpher.nl on November 25, 2015.

Het Vaderland, 1938 and 1940. Consulted via www.delpher.nl on November 25, 2015.

Het Vrije Volk, 1946. Consulted via www.delpher.nl on November 25, 2015.

De Waarheid, 1946. Consulted via www.delpher.nl on November 25, 2015.

\section{Reviews}

Anon. 'Een bekroonde Zweedsch-Finsche roman', In : Algemeen Handelsblad, March 2, 1937. Consulted via www.delpher.nl on November 25, 2015.

Anon. 'De Meest verkochte boeken in December'. In : Haagsche Post, January 15, 1938. KB, National Library of the Netherlands, The Hague. 
Anon. [review of Katrina]. In : Studiën. Tijdschrift voor godsdienst, wetenschap en letteren, 1938 (129), 277-278. Consulted via www.delpher.nl on November 25, 2015.

Anon. [review of Katrina]. In : Soerabaijasch handelsblad, December 10, 1937. Consulted via www.delpher.nl on November 25, 2015.

Anon. ‘Sally Salminen's bekroonde roman “Katrina”'. In : De Telegraaf, March 14, 1937. Consulted via www.delpher.nl on November 25, 2015.

Anon. 'Groot in beroemdheid. Groot in bescheidenheid'. In : De Tijd, August 28, 1938. Consulted via www.delpher.nl on November 25, 2015.

Anon. 'Bibliographie, SINT NICOLAAS' KEUR-COLLECTIES.' In : De Nieuwe Gids 52, December 1937, 593-594. Consulted via www.dbnl.org on November 25, 2015.

Anon. 'Kunst en Letteren Kroniek'. In : Nieuwsblad van het Noorden, April 12, 1940. Consulted via www.delpher.nl on November 25, 2015.

Anon. 'Van de leestafel. De Amerikaansche succes-roman'. In : Limburger Koerier, June 20, 1938. Consulted via www.delpher.nl on November 25, 2015.

Gerard van Eckeren 'Het boek van de week' [review of Gone with the Wind first volume and Robert Nathan The Enchanted Voyage]. In : Eigen Haard 1937, 822-823.

J.G. de Haas 'Katrina'. In : Nieuwsblad van het Noorden, May 1, 1937. Consulted via www.delpher.nl on November 25, 2015.

P. Hardy, [review of Katrina]. In : Boekengids 1937, 343-344. Consulted via www.dbnl.org on November 25, 2015.

Bertil Jörnson 'Uit het hooge Noorden'. In : Leeuwarder courant, February 27,1937. Consulted via www.delpher.nl on November 25, 2015.

A.J.D. van Oosten 'Zweedsch-Finsche Literatuur'. In : De Tijd, July 12, 1937. Consulted via www.delpher.nl on November 25, 2015.

V. Pearce Delgado 'Literatuur in Amerika. De historie leeft'. In : Het Vaderland, November 1, 1936. Consulted via www.delpher.nl on November 25, 2015.

A. Romein-Verschoor 'Periscoop' [review of Katrina]. In : Critisch Bulletin, 1937, 206.

J. van Schaik-Willing 'Kracht en artisticiteit' [review of Gone with the Wind]. In : Critisch Bulletin 1937, 79-82.

L. Schoenmakers [review of Gone with the Wind]. In : Boekengids 1938, 77. Consulted via www.dbnl.org on November 25, 2015.

Gabriël Smit 'Een bekroonde roman'. In : De Gooi- en Eemlander : nieuws- en advertentieblad, May 2, 1937. Consulted via www.delpher.nl on November 25, 2015.

C. Tazelaar 'Over de trilogie van Margareth Michell [sic]'. In : Stemmen des Tijds 1938, 81-89.

Consulted via www.delpher.nl on November 25, 2015.

\section{Figures}

Figure $1: N v d B$, November 6, 1936. http://resolver.kb.nl/resolve?urn=dts:2770065:mpeg21:0009.

Figure 2 : photograph by Rick Luimes.

Figure $3: N v d B$, October 6, 1937. http://resolver.kb.nl/resolve?urn=dts:2774041:mpeg21:0013. 
Other

Anon. “'Gone with the Wind" Pirated. Holland Publisher Sued by Margaret Mitchell”. In : The Publishers' Weekly, December 18, 1937.

Anon. “'Gone with the Wind” in Holland'. In : The Publishers' Weekly, February 19, 1938.

Anon. 'Margaret Mitchell's “Gejaagd door de wind” in beslag genomen. Auteursrechtkwestie'. In : Leeuwarder Courant , January 14, 1938. Consulted via www.delpher.nl on November 25, 2015.

Anon. 'Een nieuwe roman van Sally Salminen'. In : Rotterdamsch Nieuwsblad, January 2, 1940. Consulted via www.delpher.nl on November 25, 2015.

\section{Secondary sources}

Altick, Richard D. The English Common Reader. A Social History of the Mass Reading Public, 1800-1900. Chicago etc. : The University of Chicago Press, 1963.

Anonymus. 'Andries Blitz'. In De laatste bladzijde... Gewijd aan uitgevers, drukkers, boekhandelaren, typografen en omslagontwerpers die stierven in de oorlogsjaren 1940-1945, 8, 1995.

Anten, Hans. Van realisme naar zakelijkheid. Proza-opvattingen tussen 1916 en 1932. Reflex, 1982.

Ardis, Ann L. Modernism and Cultural Conflict. 1880 - 1922. Cambridge : Cambridge Univ. Press, 2008.

Biesemans, Els, and G. L. M. Laureys. 'The Reception of Scandinavian Literature in the Netherlands and Flanders 1860-1940'. In Rethinking Cultural Transfer and Transmission. Reflections and New Perspectives, edited by Petra Broomans and Sandra van Voorst, 75-92. Groningen : Barkhuis, 2012.

Bloom, Clive. Bestsellers. Popular Fiction since 1900. Basingstoke etc. : Palgrave Macmillan, 2008.

Bondestam, Anna, ed. Sallys Saga. En bok om Sally Salminen till 50-årsminnet av 'Katrina'. Helsingfors : Schildt, 1986.

Bourdieu, Pierre. Distinction. A Social Critique of the Judgement of Taste. Edited by Richard Nice. London : Routledge, 2006.

Boven, Erica van. '4 ‘Laat óns het geestelijk leven'. De elite en de publieksliteratuur in het interbellum'. In Van spiegels en vensters. De literaire canon in Nederland, edited by Lizet Duyvendak and Saskia Pieterse, 45-70. Hilversum : Verloren, 2009.

- - - Bestsellers in Nederland 1900-2015. Antwerpen / Apeldoorn : Garant, 2015.

'Cultuurdebat in Nederland. De gemiddelde lezer contra 'intellectualisme' in de late jaren dertig'. Spiegel der Letteren 54, no. 3 (2012) : 353-68.

-_-. 'De middlebrow-roman schrijft terug. Visies op elite en "hoge literatuur" in enkele publieksromans rond 1930’. TNTL 125 (2009) : 285-305.

-_- Een hoofdstuk apart. 'Vrouwenromans' in de literaire kritiek 1898-1930. Amsterdam : Sara/Van Gennep, 1992.

. 'Hollandse helden. Gemeenschap en natie in middlebrowromans'. Nederlandse Letterkunde 18, no. 3 (2013) : 147-60. 
Boven, Erica van, and Mathijs Sanders. 'Strijd om het middenveld. Middlebrow in de literaire kritiek : Menno ter Braak en P.H. Ritter Jr.' Vooys 29, no. 1/2 (2011) : 17-27.

Broomans, Petra. 'Scandinavische literatuur in Nederland : verslonden, verzuild en verguisd'. In In 1934. Nederlandse cultuur in internationale context, edited by Helleke van den Braber and J. A. W. Gielkens, 407-14. Amsterdam etc. : Querido, 2010.

---. Zweedse en Zweedstalige Finse auteurs in Nederlandse vertaling, 1491-2007. Een bibliografie. Studies on Cultural Transfer and Transmission. Groningen : Barkhuis, 2013. Casanova, Pascale. The World Republic of Letters. Cambridge, MA etc. : Harvard University Press, 2004.

Collini, Stefan. 'Chapter 5 : Highbrows and Other Aliens'. In Absent Minds. Intellectuals in Britain. Oxford etc. : Oxford University Press, 2006.

Dorleijn, Gillis. 'Grensverkeer in de media. De "Selbstinszenierung” van de auteur in literaire interviews'. In Out of the Box. Über den Wert des Grenzwertigen, edited by Emmeline Besamusca, Christine Hermann and Ulrike Vogl, 83-101. Wien : Praesens Verlag, 2013.

Dorleijn, Gillis, and Pieter Verstraeten. 'L'interview littéraire aux Pays-Bas. L'institutionnalisation d'un genre complexe'. Forthcoming.

Driscoll, Beth. The New Literary Middlebrow. Tastemakers and Reading in the Twenty-First Century. Basingstoke : Palgrave Macmillan, 2014.

Even-Zohar, Itamar. 'The Position of Translated Literature within the Literary Polysystem'. Poetics Today 11, no. 1 (1990) (Special Issue : Polysystem Studies) : 45-52.

Farr, Finis. Margaret Mitchell of Atlanta. The Author of 'Gone with the Wind'. New York : Morrow, 1965.

Fuks-Mansfeld, Renate Gertrud. 'Blits, Andries uitgever'. In Joden in Nederland in de twintigste eeuw. Een biografisch woordenboek, 28-29, 2007.

Galow, Timothy W. Writing Celebrity. Stein, Fitzgerald, and the Modern(ist) Art of SelfFashioning. American Literature Readings in the Twenty-First Century. New York : Palgrave Macmillan, 2011.

Hammond, Mary. Reading, Publishing and the Formation of Literary Taste in England, 1880-1914. The Nineteenth Century. Aldershot etc. : Ashgate, 2006.

Holmström, Roger. ‘Against All Odds. Sally Salminen's Katrina and the Possibilities of Cultural Transfer'. In Battles and Borders. Perspectives on Cultural Transmission and Literature in Minor Language Areas, edited by Petra Broomans, Goffe Jensma, Ester Jiresch, Janke Klok, and Roald van Elswijk, 97-107. Studies on Cultural Transfer and Transmission 7, 2015.

Hubregtse. 'Uitgeverij de Arbeiderspers. Van ontstaan tot en met ontzuiling'. In Het zevende jaarboek voor het democratisch socialisme, edited by Marnix Krop, Martin Ros, Saskia Stuiveling, and Bart Tromp, 132-67, 1986.

Humble, Nicola. The Feminine Middlebrow Novel, 1920s to 1950s. Class, Domesticity, and Bohemianism. Oxford etc. : Oxford University Press, 2001.

Huyssen, Andreas. 'Mass Culture as Woman : Modernism's Other'. In After the Great Divide. Modernism, Mass Culture, Postmodernism, 44-62. 399. Bloomington etc. : Indiana University press, 1986. 
Kalinowski, Isabelle. 'Der Französische Hölderlin, Theorie des Literarischen Feldes und Rezeptionsforschung'. In Text und Feld. Bourdieu in der Literaturwissenschaftlichen Praxis, edited by Markus Joch and Norbert Christian Wolf, 247-60. Tübingen : Niemeyer, 2005.

Keltjens, Ryanne. “'The Miraculous Secret of a Good Book” : Representations of the Reading Experience in Dutch Middlebrow Criticism'. Reading Today. London : UCL Press, forthcoming.

Korda, Michael. Making the List. A Cultural History of the American Bestseller, 1900-1999. New York: Barnes \& Noble Books, 2001.

Krevelen, L. van. 'Van liefhebberij tot cultureel ondernemerschap. Over de ontwikkeling van de literaire uitgeverijen in Nederland'. Jaarboek voor Nederlandse boekgeschiedenis 10 (2003) : 1350.

Mitchell, Margaret Munnerlyn, and Richard Barksdale Harwell, eds. Margaret Mitchell's ‘Gone with the Wind' Letters, 1936-1949. London : Sidgwick \& Jackson, 1987.

Pollentier, Caroline. 'Configuring Middleness : Bourdieu, L'art Moyen and the Broadbrow'. In Middlebrow Literary Cultures. The Battle of the Brows, 1920-1960, edited by Erica Brown and Mary Grover, 37-51. New York etc. : Palgrave Macmillan, 2012.

Pyron, Darden Asbury. Southern Daughter. The Life of Margaret Mitchell. New York, N.Y. etc. : Oxford University Press, 1991.

Radway, Janice A. A Feeling for Books. The Book-of-the-Month Club, Literary Taste, and MiddleClass Desire. Chapel Hill etc. : University of North Carolina Press, 1997.

Ricketson, Sam. The Berne Convention for the Protection of Literary and Artistic Works : 1886-1986. London / Deventer : Centre for Commercial Law Studies, Queen Mary College, University of London / Kluwer, 1987.

Rosmalen, Jo van. 'Economische wederwaardigheden van boekhandel en uitgeverij tussen de jaren 1877 en 1977'. In Het lam voor de glazen. Opstellen over een eeuw boekbedrijf : 1877-1977, edited by Dingeman van der Stoep, 128-52. Baarn : Ambo, 1977.

Rubin, Joan Shelley. 'Introduction'. In The Making of Middlebrow Culture, xi - xx. Chapel Hill etc. : University of North Carolina Press, 1992.

-- . The Making of Middlebrow Culture. Chapel Hill etc. : University of North Carolina Press, 1992.

Sanders, Mathijs. 'De criticus als bemiddelaar. Middlebrow en de Nederlandse literaire kritiek in het interbellum'. Tijdschrift voor Nederlandse Taal- en Letterkunde 124, no. 4 (2008) : 312-33.

- - . 'Het buitenland bekeken'. In In 1934. Nederlandse cultuur in internationale context, 30112. Querido, 2010.

Sanders, Mathijs, and Erica van Boven. 'A Cream Pie with Rat Poison. La Madone in the Netherlands'. Relief 9, no. 1 (2015) : 77-88.

Sanders, Mathijs, and Alex Rutten. 'Who Framed Edgar Wallace? British Popular Fiction in the Netherlands'. In Transitions in Middlebrow Writing, 1880-1930, edited by Kate Macdonald and Christoph Singer, 223-41. Basingstoke : Palgrave Macmillan, 2015.

Sapiro, Gisèle. 'Les professions intellectuelles entre l'État, l'entrepreneuriat et l'industrie'. Le Mouvement Social 214, no. 1 (2006) : 3 .

-_-. 'The Literary Field between the State and the Market'. Poetics 31, no. 5-6 (2003) : 441-64. 
Schriks, Christiaan F. J. Charles Gl. Behrens. Portret van een journalist, vertaler, schrijver, boekverzorger, illustrator, graficus en briefschrijver. Zutphen : Walburg Pers, 1994.

Weel, Adriaan van der. 'Dutch Nineteenth-Century Attitudes to International Copyright'. Publishing History 47 (2000) : 31-44.

---. 'Het "hardnekkige isolement" van Nederland in de geschiedenis van de toetreding tot de Berner Conventie.' Van het boek en de rand. Boeketje boekwetenschap, 2013, 26-31.

Weel, Adriaan Hendrik van der. Onbehagen in de schriftcultuur. Leesrevoluties in de negentiende en twintigste eeuw. LUP Oraties. Amsterdam : Leiden University Press, 2007.

\section{ENDNOTES}

i. Pascale Casanova, The World Republic of Letters, Convergences (Cambridge, MA etc.: Harvard University Press, 2004), 170-171.

ii. Cf. Timothy W. Galow, Writing Celebrity. Stein, Fitzgerald, and the Modern(ist) Art of Self-Fashioning, (New York: Palgrave Macmillan, 2011).

iii. Cf. Casanova, The World Republic of Letters, 170; Margaret Munnerlyn Mitchell and Richard Barksdale Harwell, eds., Margaret Mitchell's 'Gone with the Wind' Letters, 1936-1949 (London: Sidgwick \& Jackson, 1987), xxviii. Recent sales numbers are unknown to me. The production of the Gone with the Wind motion picture was delayed, but negotiations about the film rights started right away after the publication of the novel.

iv. Clive Bloom, Bestsellers. Popular Fiction since 1900 (Basingstoke etc.: Palgrave Macmillan, 2008), 32; Cf. Richard D. Altick, The English Common Reader. A Social History of the Mass Reading Public, 1800-1900 (Chicago etc.: The University of Chicago Press, 1963).

v. Bloom, Bestsellers, 30-32; Altick, The English Common Reader, 141-187; Cf. Mary Hammond, Reading, Publishing and the Formation of Literary Taste in England, 1880-1914, The Nineteenth Century (Aldershot etc.: Ashgate, 2006), 3-4.

vi. Stefan Collini, 'Chapter 5: Highbrows and Other Aliens', in Absent Minds. Intellectuals in Britain (Oxford etc.: Oxford University Press, 2006), 110-119. About the role of these intermediaries, see: Gisèle Sapiro, 'The Literary Field between the State and the Market', Poetics 31, no. 5-6 (2003): 451; Pierre Bourdieu, Distinction. A Social Critique of the Judgement of Taste, ed. Richard Nice (London: Routledge, 2006), 325.

vii. Pioneering works in middlebrow studies include: Joan Shelley Rubin, The Making of Middlebrow Culture (Chapel Hill etc.: University of North Carolina Press, 1992); Janice A. Radway, A Feeling for Books. The Book-of-the-Month Club, Literary Taste, and Middle-Class Desire (Chapel Hill etc.: University of North Carolina Press, 1997); Ann L. Ardis, Modernism and Cultural Conflict. 1880 - 1922 (Cambridge: Cambridge Univ. Press, 2008).

viii. Ardis, Modernism and Cultural Conflict, 116.

ix. About the relation of middlebrow to Bourdieu's conception of the literary field, see: Beth Driscoll, The New Literary Middlebrow. Tastemakers and Reading in the Twenty-First Century (Basingstoke: Palgrave Macmillan, 2014) (introduction); and: Caroline Pollentier, 'Configuring Middleness: Bourdieu, L'art Moyen and the Broadbrow', in Middlebrow Literary Cultures. The Battle of the Brows, 1920-1960, ed. Erica Brown and Mary Grover (New York etc.: Palgrave Macmillan, 2012), 37-51.

x. Cf. Mathijs Sanders and Alex Rutten, 'Who Framed Edgar Wallace? British Popular Fiction in the Netherlands', in Transitions in Middlebrow Writing, 1880-1930, ed. Kate Macdonald and Christoph Singer (Basingstoke: Palgrave Macmillan, 2015), 223-41. 
xi. Cf. ibid., 226. Such complaints at least date back to the 19th century. Cf. Adriaan Hendrik van der Weel, Onbehagen in de schriftcultuur. Leesrevoluties in de negentiende en twintigste eeuw, (Amsterdam: Leiden University Press, 2007), 17. At the same time, critics complained that foreign quality works remained unknown in the Netherlands. Cf. Mathijs Sanders and Erica van Boven, 'A Cream Pie with Rat Poison. La Madone in the Netherlands', Relief 9, no. 1 (2015): 77-78.

xii. L. van Krevelen, 'Van liefhebberij tot cultureel ondernemerschap. Over de ontwikkeling van de literaire uitgeverijen in Nederland', Jaarboek voor Nederlandse boekgeschiedenis 10 (2003): 13-14.

xiii. Itamar Even-Zohar, 'The Position of Translated Literature within the Literary Polysystem', Poetics Today. 11, no. 1 (1990): 47-48. During the nineteen-twenties, sixty to seventy per cent of the published novels were translations. Sanders and Rutten, 'Who Framed Edgar Wallace? British Popular Fiction in the Netherlands', 226. About the current situation in Europe, cf. Casanova, The World Republic of Letters, 168.

xiv. Christiaan F. J. Schriks, Charles Gl. Behrens: portret van een journalist, vertaler, schrijver, boekverzorger, illustrator, graficus en briefschrijver (Zutphen: Walburg Pers, 1994), 27.; NvdB, December 7, 1939; NvdB, November 8, 1939.

xv. His original name was Blits, but he used this dynamic spelling variant for his publishing house.

xvi. $N v d B$, November 8, 1939; $N v d B$, November 15, 1939.

xvii. This feast is somewhat comparable to Christmas.

xviii. Hubregtse, 'Uitgeverij de Arbeiderspers: van ontstaan tot en met ontzuiling', in Het zevende jaarboek voor het democratisch socialisme, ed. Marnix Krop et al., 1986, 146; For more information about Blitz, see: Renate Gertrud Fuks-Mansfeld, 'Blits, Andries uitgever', in Joden in Nederland in de twintigste eeuw. Een biografisch woordenboek, 2007, 28-29; and Anonymus, 'Andries Blitz', in De laatste bladzijde... Gewijd aan uitgevers, drukkers, boekhandelaren, typografen en omslagontwerpers die stierven in de oorlogsjaren 1940-1945, 1995, 8.

xix. For this innovation Blitz cooperated with the socialist publishing house De Arbeiderspers (The Worker's Press). Hubregtse, 'Uitgeverij de Arbeiderspers: van ontstaan tot en met ontzuiling', 146-147.

xx. Fuks-Mansfeld, 'Blits, Andries uitgever'; Anonymus, 'Andries Blitz'.

xxi. Schriks, Charles Gl. Behrens, 24, 27-28; Fuks-Mansfeld, 'Blits, Andries uitgever', 28.

xxii. Erica van Boven, Bestsellers in Nederland 1900-2015 (Antwerpen / Apeldoorn: Garant, 2015), 9092. About the reception of Scandinavian literature in the Netherlands, see: Petra Broomans, 'Scandinavische literatuur in Nederland: verslonden, verzuild en verguisd', in In 1934. Nederlandse cultuur in internationale context, ed. Helleke van den Braber and J. A. W. Gielkens (Amsterdam etc.: Querido, 2010), 407-14; Els Biesemans and G. L. M. Laureys, 'The Reception of Scandinavian Literature in the Netherlands and Flanders 1860-1940', in Rethinking Cultural Transfer and Transmission. Reflections and New Perspectives, ed. Petra Broomans and Sandra van Voorst (Groningen: Barkhuis, 2012), 75-92.

xxiii. The information in this paragraph is mainly derived from: Roger Holmström, 'Against All Odds. Sally Salminen's Katrina and the Possibilities of Cultural Transfer', in Battles and Borders. Perspectives on Cultural Transmission and Literature in Minor Language Areas, ed. Petra Broomans et al., Studies on Cultural Transfer and Transmission 7, 2015, 97-107; Cf. Anna Bondestam, ed., Sallys Saga: en bok om Sally Salminen till 50-årsminnet av 'Katrina' (Helsingfors: Schildt, 1986).

xxiv. His first advertisement for the novel dates November 6, 1936.

xxv. $N v d B$, February 10, 1937.

xxvi. All quotes were translated by the author.

xxvii. Cf. Holmström, 'Against All Odds. Sally Salminen's Katrina and the Possibilities of Cultural Transfer', 103.

xxviii. Anon. 'Een nieuwe roman van Sally Salminen'. In: Rotterdamsch Nieuwsblad, January 2, 1940. 
xxix. Galow, Writing Celebrity, 3.

xxx. Gillis Dorleijn, “Grensverkeer in de media. De "Selbstinszenierung” van de auteur in literaire interviews', in Out of the Box. Über den Wert des Grenzwertigen, ed. Emmeline Besamusca, Christine Hermann and Ulrike Vogl (Wien: Praesens Verlag, 2013), 87; Cf. Gillis Dorleijn and Pieter Verstraeten, 'L'interview littéraire aux Pays-Bas. L'institutionnalisation d'un genre complexe', forthcoming.

xxxi. Ibid., 84-86; Cf. Galow, Writing Celebrity, 18-19.

xxxii. Dorleijn, "Grensverkeer in de media. De "Selbstinszenierung" van de auteur in literaire interviews', 84-86.

xxxiii. Cf. Galow, Writing Celebrity, 29.

xxxiv. Anon. 'De Meest verkochte boeken in December'. In: Haagsche Post, January 15, 1938. This first monthly bestseller list in the Netherlands existed from 1933 until 1939. Van Boven, Bestsellers in Nederland 1900-2015, 44-45. Of course one should be careful with this information, because bestseller lists are by definition unreliable and offer no exact sales numbers. For the lack of reliable (historical) information on book sales, see: Bloom, Bestsellers, 28 and further.

xxxv. NvdB, November 1, 1939; De Telegraaf, March 1, 1950.

xxxvi. Petra Broomans, Zweedse en Zweedstalige Finse auteurs in Nederlandse vertaling, 1491-2007. Een bibliografie, Studies on Cultural Transfer and Transmission, (Groningen: Barkhuis, 2013), 285-286; Cf. Schriks, Charles Gl. Behrens, 27-28.

xxxvii. Fuks-Mansfeld, 'Blits, Andries uitgever'.

xxxviii. Ibid.; Hubregtse, 'Uitgeverij de Arbeiderspers: van ontstaan tot en met ontzuiling', 148. xxxix. Hubregtse, 'Uitgeverij de Arbeiderspers: van ontstaan tot en met ontzuiling', 156.

xl. The title of her lecture was: 'Noren, Zweden, Finnen en Denen, hun overeenkomsten en tegenstellingen'. De Waarheid, June 5, 1946; De Waarheid, June 13, 1946; Het Vrije Volk, June 19, 1946. xli. Anon. 'Een bekroonde Zweedsch-Finsche roman', In: Algemeen Handelsblad, March 2, 1937; J.G. de Haas 'Katrina'. In: Nieuwsblad van het Noorden, May 1, 1937.

xlii. Mathijs Sanders, 'Het buitenland bekeken', in In 1934. Nederlandse cultuur in internationale context (Querido, 2010), 303. Sanders used the Dutch national bibliography (Brinkman's Catalogue) for his analysis of the situation in 1934. Works translated from English and American English accounted for $27,3 \%$ of the fiction production, Danish, Norwegian and Swedish works together accounted for 3,4\%, whereas for instance no Spanish works were translated into Dutch in 1934.

xliii. De Haas 'Katrina'; Anon. 'Een bekroonde Zweedsch-Finsche roman'.

xliv. De Haas 'Katrina'.

xlv. P. Hardy, [review of Katrina]. In: Boekengids 1937, 343-344; De Haas 'Katrina'.

xlvi. De Haas 'Katrina'.

xlvii. P. Hardy, [review of Katrina].

xlviii. Anon. [review of Katrina]. In: Studiën. Tijdschrift voor godsdienst, wetenschap en letteren, 1938 (129), 277-278.

xlix. De Haas 'Katrina'; Anon. [review of Katrina]. In: Soerabaijasch handelsblad, December 10, 1937. 1. Anon. 'Sally Salminen's bekroonde roman "Katrina”. In: De Telegraaf, March 14, 1937; Gabriël Smit 'Een bekroonde roman'. In: De Gooi- en Eemlander : nieuws- en advertentieblad, May 2, 1937.

li. Gabriël Smit 'Een bekroonde roman'.

lii. Cf. Ryanne Keltjens, “The Miraculous Secret of a Good Book”: Representations of the Reading Experience in Dutch Middlebrow Criticism', Forthcoming; Erica van Boven, 'Cultuurdebat in Nederland. De gemiddelde lezer contra 'intellectualisme' in de late jaren dertig', spiegel der Letteren 54, no. 3 (2012): 359-360.

liii. De Haas 'Katrina'.

liv. Sanders and Rutten, 'Who Framed Edgar Wallace? British Popular Fiction in the Netherlands', 234-235.

lv. De Haas 'Katrina'. (emphasis added) 
lvi. Cf. Van Boven, 'Cultuurdebat in Nederland. De gemiddelde lezer contra 'intellectualisme' in de late jaren dertig', 358.

lvii. Sanders and Rutten, 'Who Framed Edgar Wallace? British Popular Fiction in the Netherlands', 233-236; Erica van Boven, 'Hollandse helden. Gemeenschap en natie in middlebrowromans', Nederlandse Letterkunde 18, no. 3 (2013): 158.

lviii. Cf. Van Boven, 'Cultuurdebat in Nederland. De gemiddelde lezer contra 'intellectualisme' in de late jaren dertig'; Erica van Boven and Mathijs Sanders, 'Strijd om het middenveld. Middlebrow in de literaire kritiek: Menno ter Braak en P.H. Ritter Jr.', Vooys 29, no. 1/2 (2011): 17-27; Keltjens, "'The Miraculous Secret of a Good Book": Representations of the Reading Experience in Dutch Middlebrow Criticism'.

lix. Mathijs Sanders, 'De criticus als bemiddelaar. Middlebrow en de Nederlandse literaire kritiek in het interbellum', Tijdschrift voor Nederlandse Taal- en Letterkunde 124, no. 4 (2008): 312-33; Sanders and Rutten, 'Who Framed Edgar Wallace? British Popular Fiction in the Netherlands'; Cf. Joan Shelley Rubin, 'Introduction', in The Making of Middlebrow Culture (Chapel Hill etc.: University of North Carolina Press, 1992), xvi.

lx. Van Boven, 'Cultuurdebat in Nederland. De gemiddelde lezer contra 'intellectualisme' in de late jaren dertig', 358-359, 364.

lxi. Cf. Galow, Writing Celebrity, 27, 29.

lxii. De Haas 'Katrina'; Anon. [review of Katrina]. In: Studiën; Anon. [review of Katrina]. In: Soerabaijasch handelsblad; Bertil Jörnson 'Uit het hooge Noorden'. In: Leeuwarder courant, February 27,1937; Anon. 'Sally Salminen's bekroonde roman “Katrina”'. In: De Telegraaf.

lxiii. Anon. [review of Katrina]. In: Soerabaijasch handelsblad; A. Romein-Verschoor 'Periscoop' [review of Katrina]. In: Critisch Bulletin, 1937, 206; Anon. 'Sally Salminen's bekroonde roman “Katrina”'. In: De Telegraaf; De Haas 'Katrina'.

lxiv. A.J.D. van Oosten 'Zweedsch-Finsche Literatuur'. In: De Tijd, July 12, 1937; De Haas 'Katrina'; Anon. [review of Katrina]. In: Soerabaijasch handelsblad.

lxv. Anon. 'Groot in beroemdheid. Groot in bescheidenheid'. In: De Tijd, August 28, 1938. Cf. Het Vrije Volk, June 19, 1946.

lxvi. Pieck also took care of the illustrations in the Dutch translation of Gulbranssen's Björndal Trilogy (ZHUM, 1935-1936). Broomans, 'Scandinavische literatuur in Nederland: verslonden, verzuild en verguisd', 409, 412.

lxvii. The novel was translated by W.J.A. Roldanus Jr.

lxviii. Cf. Gerard van Eckeren 'Het boek van de week' [review of Gone with the Wind first volume and Robert Nathan The Enchanted Voyage]. In: Eigen Haard 1937, 822-823, 822.

lxix. Mitchell and Harwell, Margaret Mitchell's 'Gone with the Wind' Letters, 1936-1949, xxvii; Michael Korda, Making the List: A Cultural History of the American Bestseller, 1900-1999 (New York: Barnes \& Noble Books, 2001), 59.

lxx. Jo van Rosmalen, 'Economische wederwaardigheden van boekhandel en uitgeverij tussen de jaren 1877 en 1977', in Het lam voor de glazen: opstellen over een eeuw boekbedrijf: 1877-1977, ed. Dingeman van der Stoep (Baarn: Ambo, 1977), 144.

lxxi. NvdB, March 30, 1938.

lxxii. Anon. 'Van de leestafel. De Amerikaansche succes-roman'. In: Limburger Koerier, June 20, 1938.

lxxiii. Hans Anten, Van realisme naar zakelijkheid. Proza-opvattingen tussen 1916 en 1932 (Reflex, 1982), 9, 13-32; Erica van Boven, Een hoofdstuk apart. 'Vrouwenromans' in de literaire kritiek 1898-1930 (Amsterdam: Sara/Van Gennep, 1992), 66-67.

lxxiv. NvdB, October 6, 1937; The original edition was published on June 30, 1936. Finis Farr, Margaret Mitchell of Atlanta: The Author of 'Gone with the Wind' (New York: Morrow, 1965), 1.

lxxv. $N v d B$, October 6, 1937

lxxvi. Amongst others: De Telegraaf, February 9, 1940; Het Vaderland, January 17, 1940. 
lxxvii. Cf. Gisèle Sapiro, 'Les professions intellectuelles entre l'État, l'entrepreneuriat et l'industrie', Le Mouvement Social 214, no. 1 (2006): 9.

lxxviii. Darden Asbury Pyron, Southern Daughter: The Life of Margaret Mitchell (New York, N.Y. etc.: Oxford University Press, 1991), 449.; Anon. "'Gone with the Wind" Pirated. Holland Publisher Sued by Margaret Mitchell”. In: The Publishers' Weekly, December 18, 1937.

lxxix. NvdB, January 19, 1938; Anon. '“Gone with the Wind” in Holland'. In: The Publishers' Weekly, February 19, 1938.

lxxx. Anon. "“Gone with the Wind” in Holland'; Cf. Het Vaderland March 20, 1938.

lxxxi. Mitchell and Harwell, Margaret Mitchell's ‘Gone with the Wind' Letters, 1936-1949, 197.

lxxxii. Pyron, Southern Daughter, 422-423; Farr, Margaret Mitchell of Atlanta, 172-173, 221.

lxxxiii. The US joined the Berne Convention in 1989. Cf. http://www.wipo.int/treaties/en/ip/ berne/ (Visited on November 25, 2015); Sam Ricketson, The Berne Convention for the Protection of Literary and Artistic Works: 1886-1986 (London / Deventer: Centre for Commercial Law Studies, Queen Mary College, University of London / Kluwer, 1987), 923.

lxxxiv. Ibid., 924; Pyron, Southern Daughter, 449.

lxxxv. Anon. "'Gone with the Wind" Pirated. Holland Publisher Sued by Margaret Mitchell”; Mitchell and Harwell, Margaret Mitchell's 'Gone with the Wind' Letters, 1936-1949, 196-197. Cf. NvdB, March 2, 1938; NvdB, May 10, 1939.

lxxxvi. Anon. "“Gone with the Wind" in Holland'.; NvdB, January 19, 1938. This Committee was part of the Vereeniging ter Bevordering van de Belangen des Boekhandels (Association for Promoting the Interests of the Book Trade). Cf. Adriaan van der Weel, 'Dutch Nineteenth-Century Attitudes to International Copyright', Publishing History 47 (2000): 33.

lxxxvii. Anon. "'Gone with the Wind" in Holland'.

lxxxviii. Pyron, Southern Daughter, 449-452.

lxxxix. Ibid., 431.

xc. Amongst others: De Telegraaf January 3, 1938; NvdB, January 5, 1938; Anon. 'Margaret Mitchell's "Gejaagd door de wind" in beslag genomen. Auteursrechtkwestie'. In: Leeuwarder Courant , January 14, 1938.

xci. $N v d B$, January $19,1938$.

xcii. Mitchell and Harwell, Margaret Mitchell's 'Gone with the Wind' Letters, 1936-1949, 197.; Statement of De Uitgever, February 1938, translated and reproduced in: Anon. "“Gone with the Wind" in Holland'.; Cf. NvdB, January 5, 1938.

xciii. $N v d B$, January 5, 1938; The author is referring to: Anon. "“Gone with the Wind" Pirated. Holland Publisher Sued by Margaret Mitchell”; Cf: NvdB, March 16, 1938.

xciv. The Netherlands themselves were in fact rather late in fully implementing copyright law, as compared to other European countries. Adriaan van der Weel, "Het "hardnekkige isolement" van Nederland in de geschiedenis van de toetreding tot de Berner Conventie.', Van het boek en de rand: boeketje boekwetenschap III, 2013, 26-31.

xcv. Casanova, The World Republic of Letters, 170-171; Cf. Van der Weel, 'Dutch Nineteenth-Century Attitudes to International Copyright', 40-42.

xcvi. Van der Weel, 'Dutch Nineteenth-Century Attitudes to International Copyright'.

xcvii. The edition was published in December 1945. Pyron, Southern Daughter, 450.

xcviii. Het Vaderland, March 20, 1938.

xcix. C. Tazelaar 'Over de trilogie van Margareth Michell [sic]'. In: Stemmen des Tijds 1938, 81-89, 89; J. van Schaik-Willing 'Kracht en artisticiteit' [review of Gone with the Wind]. In: Critisch Bulletin 1937, 79-82, 80.

c. Anon. 'Bibliographie, SINT NICOLAAS' KEUR-COLLECTIES.' In: De Nieuwe Gids 52, December 1937, 593-594; Anon. 'Kunst en Letteren Kroniek'. In: Nieuwsblad van het Noorden, April 12, 1940.

ci. Cf. Radway's description of the values and tastes middlebrow critics promoted as 'a kind of social pedagogy'. Radway, A Feeling for Books, 15; Cf. Van Boven, 'Cultuurdebat in Nederland. De 
gemiddelde lezer contra 'intellectualisme' in de late jaren dertig', 366; Nicola Humble, The Feminine Middlebrow Novel, 1920s to 1950s: Class, Domesticity, and Bohemianism (Oxford etc.: Oxford University Press, 2001), 47-50.

cii. Anon. 'Van de leestafel. De Amerikaansche succes-roman'.

ciii. V. Pearce Delgado 'Literatuur in Amerika. De historie leeft'. In: Het Vaderland, November 1, 1936.

civ. Van Schaik-Willing 'Kracht en artisticiteit', 81.

cv. These responses coincided with international reactions on the novel. Cf. Pyron, Southern Daughter, 432.

cvi. Van Eckeren, 'Het boek van de week', 822.

cvii. L. Schoenmakers [review of Gone with the Wind]. In: Boekengids 1938, 77; Anon. 'Van de leestafel. De Amerikaansche succes-roman'; Anon. 'Bibliographie, SINT NICOLAAS' KEURCOLLECTIES.'

cviii. Van Schaik-Willing, 'Kracht en artisticiteit'.

cix. Van Schaik-Willing 'Kracht en artisticiteit', 80.

cx. Van Boven, Een hoofdstuk apart.

cxi. Erica van Boven, 'De middlebrow-roman schrijft terug. Visies op elite en "hoge literatuur" in enkele publieksromans rond 1930', TNTL 125 (2009): 285-305.

cxii. Cf. Andreas Huyssen, 'Mass Culture as Woman: Modernism's Other', in After the Great Divide: Modernism, Mass Culture, Postmodernism, 399 (Bloomington etc.: Indiana University press, 1986), 44-62; Erica van Boven, '4 'Laat óns het geestelijk leven'. De elite en de publieksliteratuur in het interbellum', in Van spiegels en vensters. De literaire canon in Nederland, ed. Lizet Duyvendak and Saskia Pieterse (Hilversum: Verloren, 2009), 62-64; Humble, The Feminine Middlebrow Novel, 1920s to 1950 s, 18.

cxiii. Cf. Sanders and Rutten, 'Who Framed Edgar Wallace? British Popular Fiction in the Netherlands', 227; Keltjens, “"The Miraculous Secret of a Good Book”: Representations of the Reading Experience in Dutch Middlebrow Criticism'.

cxiv. Isabelle Kalinowski, 'Der Französische Hölderlin, Theorie des Literarischen Feldes und Rezeptionsforschung', in Text und Feld: Bourdieu in der Literaturwissenschaftlichen Praxis, ed. Markus Joch and Norbert Christian Wolf (Tübingen: Niemeyer, 2005), 248.

cxv. Ibid., 259-260.

cxvi. The author wants to thank Anne-Fleur van der Meer for gathering some of the material, and Petra Broomans, Erica van Boven, Mathijs Sanders, Pieter Verstraeten, Meriel Benjamins and Alex Rutten for their commentary on earlier versions of this article.

\section{ABSTRACTS}

With the emergence of an international bestseller culture in the first half of the twentieth century, foreign literary works were of increasing importance in domestic conceptions of cultural hierarchies. This was in particular the case in peripheral literary systems, which largely depended on translations of foreign novels to meet the growing demands for literary works in this period. Using the international bestsellers Gone with the Wind (1936) by the American author Margaret Mitchell and Katrina (1936) by the Finnish author Sally Salminen as case studies, this article aims to investigate how such works were adapted, marketed and evaluated in the peripheral Dutch literary field of the late thirties. Analyzing publishers' production and marketing strategies on the one hand and the evaluating practices of literary reviewers on the other, an overview is presented of the ways in which different aspects of this upcoming international bestseller culture influenced the Dutch literary field, focusing in particular on the incorporation of these international bestsellers into local debates. The concept of middlebrow is 
used within the framework of Bourdieu's field theory to study mechanisms of cultural distinction and the attribution of symbolic capital to these foreign works in the context of a national literary field.

\section{INDEX}

Mots-clés: international bestseller, middlebrow literature, cultural hierarchies, peripheral book market, Dutch literary field

\section{AUTHOR}

\section{RYANNE KELTJENS}

University of Groningen

Ryanne Keltjens completed a BA in Early Modern Dutch Literature and a Research Master in Literary and Cultural Studies (with distinction) at the University of Groningen, the Netherlands. She now works at the National Library of the Netherlands as a coordinator of the Digital Library of Dutch Literature (dbnl.org). At the same time she is finishing her dissertation, which explores the multi-faceted domain of Dutch middlebrow criticism in the interwar period. This PhD project is part of the research project 'Dutch Middlebrow Literature 1930-1940 : Production, Distribution, Reception', funded by The Netherlands Organisation for Scientific Research (NWO) and supervised by prof. dr. E.M.A. van Boven and dr. Mathijs Sanders. Ryanne's research interests include popular literature, (literary) periodicals, the functions of literature for readers, author representations, literary hierarchies and canon formation. Her scholarly work can be characterized by a broad, international perspective on current and past literary culture, from an institutional point of view. 